\title{
Educational actions: an action research with Family Health Strategy professionals and users
}

\author{
Ações educativas: pesquisa-ação com profissionais e usuários da Estratégia Saúde da Família \\ Acciones educativas: investigación-acción con profesionales y usuarios de la Estrategia Salud de la Familia
}

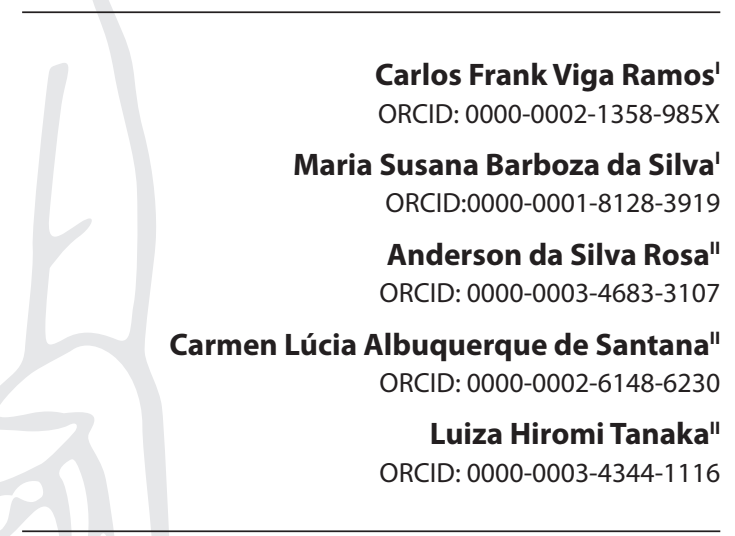

'Universidade Federal do Acre. Rio Branco, Acre, Brazil. "Universidade Federal de São Paulo. São Paulo, São Paulo, Brazil.

How to cite this article:

Ramos CFV, Silva MSB, Rosa AS, Santana CLA, Tanaka LH. Educational actions: an action research with Family Health Strategy professionals and users.

Rev Bras Enferm. 2020;73(5):e20180969. doi: http://dx.doi.org/10.1590/0034-7167-2018-0969

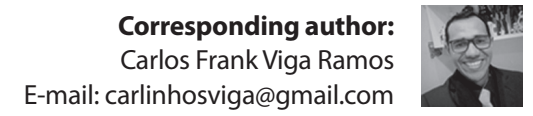

EDITOR IN CHIEF: Antonio José de Almeida Filho ASSOCIATE EDITOR: Fátima Helena Espírito Santo

Submission: 02-19-2019

Approval: 11-30-2019

\begin{abstract}
Objectives: to identify the factors that influence educational actions, and building with professionals and users proposed educational strategies that encourage popular participation. Methods: an action research, in which individual interviews, participant observation and Focus Group were conducted. Sixteen professionals and ten users from 2 Family Health Strategy from Rio Branco, Acre, Brazil participated. The results were organized by using the Thematic Analysis technique. Results: the thematic units emerged: Health education as a strategy that encourages changes in the lives of Family Health Strategy users; Critical reflection on diagnosis of the causes that interfere in educational actions in the Family Health Strategy and proposition of new strategies; Potentialities that encourage the development of educational practices at Family Heath Units; Proposals for improving educational practices focused on soft health education technology in the dialogue dimension. Conclusions: the analysis showed a lack of community ties and traditional educational strategies. In the action phase, the actors agreed to participatory changes.

Descriptors: Collective Health; Family Health; Health Education; Community Medicine; Public Health Nursing.
\end{abstract}

\section{RESUMO}

Objetivos: identificar os fatores que influenciam as ações educacionais e construir com profissionais e usuários propostas de estratégias educacionais que estimulem a participação popular. Métodos: pesquisa-ação, em que foram realizadas entrevistas individuais, observação participante e Grupo Focal. Participaram 16 profissionais e 10 usuários de 2 Estratégia Saúde da Família do Município de Rio Branco, Acre, Brasil. Os resultados foram organizados pela técnica de Análise Temática. Resultados: emergiram-se as unidades temáticas: A educação em saúde como estratégia estimuladora de mudanças na vida dos usuários da Estratégia Saúde da Família; Reflexão crítica sobre diagnóstico das causas que interferem nas ações educativas na Estratégia Saúde da Família e proposição de novas estratégias; Potencialidades que estimulam o desenvolvimento das práticas educativas na Unidade de Saúde da Família; Propostas de aprimoramento das práticas educativas centradas na tecnologia educacional leve em saúde na dimensão do diálogo. Conclusões: a análise demonstrou falta de vínculo com a comunidade e estratégias educativas tradicionais. Na fase de ação, os atores pactuaram mudanças participativas.

Descritores: Saúde Coletiva; Saúde da Família; Educação em Saúde; Medicina Comunitária; Enfermagem em Saúde Pública.

\section{RESUMEN}

Objetivos: identificar los factores que influyen en las acciones educativas y construir con profesionales y usuarios estrategias educativas propuestas que estimulen la participación popular. Métodos: investigación de acción, en la cual se realizaron entrevistas individuales, observación participante y grupo focal. Participaron 16 profesionales y 10 usuarios de 2 Estrategia de Salud Familiar de la ciudad de Rio Branco, Acre, Brasil. Los resultados fueron organizados por la técnica de Análisis temático. Resultados: surgieron unidades temáticas: Educación para la salud como una estrategia que estimula los cambios en la vida de los usuarios de Estrategia de Salud Familiar; Reflexión crítica sobre el diagnóstico de las causas que interfieren en las acciones educativas en la Estrategia de Salud Familiar y la propuesta de nuevas estrategias; Potencialidades que estimulan el desarrollo de prácticas educativas en Unidad de Salud Familiar; Propuestas para mejorar las prácticas educativas centradas en la tecnología educativa de salud ligera en la dimensión del diálogo. Conclusiones: el análisis mostró una falta de lazos comunitarios y estrategias educativas tradicionales. En la fase de acción, los actores acordaron cambios participativos.

Descriptores: Salud Pública; Salud Familiar; Educación en Salud; Medicina Comunitaria; Enfermería de Salud Pública. 


\section{INTRODUTION}

Health education in the context of public health in Brazil originated in the late nineteenth century. It was a period when health actions were aimed at maintaining and growing the economy, because the concept of health was directly related to man as being productive, who needed to have his health maintained to ensure economic development ${ }^{(1-2)}$.

With the disorderly increase of the population and the lack of health actions aimed at the large population, serious diseases such as influenza, smallpox, tuberculosis and other health problems arise. In order to combat and control the spread of these diseases, the State starts to intervene in a normative way, without respecting the right and will of the population, using an authoritarian statement. Its purpose is to inform about the actions and decisions of the bodies responsible for health policies and to implement hygienic and healthy habits through education and health ${ }^{(2)}$.

In this context, new ideals of public health policies have emerged, such as the Brazilian Unified Health System (SUS - Sistema Único de Saúde), which seeks health promotion and comprehensive care for human beings. Its strategy is the development of health care actions that contribute to the construction of a democratic, universal, equitable, integral and with the participation of the population, the result of a continuous social and political process that must be consolidated in the daily routine of health services ${ }^{(3)}$.

Given this, health education in the Family Health Strategy (FHS) incorporates and reaffirms SUS principles, becoming an indispensable tool to produce significant changes in the way of conducting the health care process. It is based on the conception of education as a potential to contribute to the development of users, in order to encourage them to reflect, develop critical awareness, exercise their autonomy, thus enabling a transformation of their reality ${ }^{(4-6)}$.

Thus, health education should be understood as a theoreticalpractical learning process that aims to integrate diverse knowledge, such as scientific, popular and common sense. Thus, it offers subsidies for the adoption of new health habits and behaviors in disease prevention and also as a means for strengthening as a citizen. It enables the individuals involved to develop a critical view on the production of health care, causing the paradigm to break with the biomedical model ${ }^{(7-8)}$.

Contrary to this ideal perception of educational practices, studies show that professionals working in the FHS end up developing disease-centered educational activities, without popular participation, especially regarding the recognition of their knowledge, with emphasis on technical knowledge, employment of hard and soft-hard technologies ${ }^{(9-13)}$.

However, other studies show that there are FHS professionals who, even with difficulties in the development of educational actions, inside or outside their governability. They strive to implement educational activities that value soft technologies based on dialogue and meaningful interaction with the community ${ }^{(11-14)}$.

\section{OBJECTIVES}

To identify the factors that influence educational actions and collectively build with professionals and users proposed educational strategies that encourage popular participation and contribute to autonomy in the production of health care.

\section{METHODS}

\section{Ethical aspects}

After approval by the Research Ethics Committee of Universidade Federal de São Paulo (Opinion 1.175.944), participants received the guidelines and signed the Informed Consent Form.

\section{Type of study}

It was outlined in the qualitative approach. It was developed in the action research modality ${ }^{(15)}$, using the Thematic Content Analysis technique for data treatmen ${ }^{(16)}$.

\section{Methodological procedures}

\section{Study setting}

This study was conducted in the city of Rio Branco (state of Acre) (Northern Brazil), with 2 FHS teams, field for Primary Health Care activities of Universidade Federal do Acre's health courses (UFAC).

\section{Study participants}

The study included 02 nurses, 10 health agents, 2 nursing technicians, 2 doctors and 10 users of two FHS teams (FHSt) in urban areas. Participants were intentionally chosen because they play a leading role in the FHSt health education process.

\section{Collection and data organization}

It was developed in two phases, exploratory and action. Contact with participants took place by invitation letter, and meetings were scheduled according to the date and place of convenience of participants. Data collection took place from September 2016 to July 2018.

In the exploratory phase, data were collected through participant observation and individual interviews guided by a semi-structured script in order to understand the meaning of health education in the health-disease process and to verify factors that influence health education practices performed by FHSt professionals and users.

In the second phase, the action, data collection took place through five Focus Group (FG) meetings, which lasted about 1 hour and 30 minutes each. Meetings discussions were guided by triggering questions, built according to the results of the analysis of data collected in the first phase and experiences of professionals from other Family Health Units (FHU), with participatory educational actions. In recent meetings, proposals were made for the improvement of health education actions by primary FHSt professionals.

After data analysis, another action was taken, the meeting with professionals and users to discuss and evaluate the proposals built and participatory educational strategies implemented by team members. 


\section{Data analysis}

Interview and focus group data were transcribed and organized using qualitative data processing software NVivo Pro 11 , version 11.4. They were analyzed according to the Thematic Content Analysis method, according to the pre-analysis phases, material exploration, treatment of results. Four thematic units emerged, and interpretation, in which the discussion of these units occurred, correlating the themes with the theoretical framework on the subject, where the contents were transformed into meaningful and valid information ${ }^{(16)}$.

\section{RESULTS}

Of the participants, four were male and 22 were female; the predominant age group was 27 to 68 years, one with specialization. The participants' professional practice time ranged from two to fifteen years; all professionals had exclusive dedication. Regarding users, all participated in educational groups, between 4 and 10 participations in educational actions.

The following Thematic Units (TUs) and their respective Units of Meaning (UMs) emerged, with the exception of TUs 2 and 4 that did not raise any meaning below those of the TUs: TU1 - Health education as a strategy that encourages changes in the lives of FHS users (UM- Participatory educational strategies that promote health, prevent diseases and encourage socialization among users); Critical reflection on diagnosis of the causes that interfere in educational actions in the FHS and proposition of new strategies; TU3 - Potentialities that encourage the development of educational practices at FHU (UM1 - Empowerment of CHAs for educational practice and UM2 - Appreciation of community participation); TU4 - Proposals for improving educational practices focused on soft health educational technology practiced in the dialogue dimension.

\section{Health education as a strategy that encourages changes in the lives of FHS users}

In this UT, it was possible to understand the perceptions of FG participants regarding participatory educational strategies that promote health, prevent disease and encourage socialization among users.

\section{UM1-Participatory educational strategies that promote health, prevent diseases and encourage socialization among users}

Even recognizing problems in relation to educational actions and their influence on people's lives, as well as the limitation of educational strategies, participants stressed the importance of rescuing the participatory and dialogical educational practices that they had developed before and that, over the years, due to the lack of encouragement, either by the recognition of SUS users and managers, or by the lack of individual personal motivation of each professional, they have been distancing themselves from the true meaning of FHS practices:

$<$ Interna/ \Focus Group 1>- § 1 coded references [0.55\% Coverage] Reference 1-0.55\% Coverage: we did school work with recyclable garbage, kids made toys with pet bottle, lids and other objects in the workshops and educational activities we did. In the end, they made presentations on the importance of preserving the environment. I think we should mature the ideas and do differently as we did before. (CHA/Blue)

Participants demonstrated, with great propriety and enthusiasm, the need to think and develop other health education strategies, especially those that strengthen the bond between professionals and users, as well as the need to intensify the encouragement of community participation in educational practices of promotion and prevention in the FHS:

\begin{abstract}
<Interna/ \Focus Group 2> - Reference 1 - 1.20\% Coverage: do other forms of health education besides lectures, such as theater. Another time I did a theater about hypertension and diabetes. It was very rich, very impacting to those who were present, because they found themselves in the situation. When we staged scenes from everyday life, they would see each other, say they would do the same thing. We can't work on this way of getting in and throwing information, because users won't absorb half of what is being said. (Nurse/Anointed)
\end{abstract}

It was possible to infer that professionals were sensitive about the need to innovate in educational actions from a dialogical and participatory context, thus being able to grasp and encourage significant changes in the lives of users and even in their own activities, as they were increasingly discouraged in the context of health care production.

Users demystified the view that they came to the unit seeking medicine and/or medical care only, emphasized that in addition to the procedures to be dispensed to them, users, they would like to establish a more interactive relationship with professionals in the sense of valorization, respect and autonomy regarding health care:

$<$ Interna/ \Focus group $5>-$ - 2 coded references [2.75\% Coverage] Reference $1-1.05 \%$ Coverage: when a person arrives at the unit and receives care, they not only need the medicine, they need to be listened to, listened to, well cared for and respected. (User/Yellow)

They promoted actions, such as conversation circles, implementation of a community garden in the unit with medicinal plants, expanded educational groups, such as adolescent health, pregnant women and childcare, as well as improved the elderly group with actions that optimized alternative spaces in the community such as forest garden, sports courts and churches.

The fact of actively including the user and the adoption of new participatory strategies has significantly transformed the way the community perceives health education, because with the opportunity to also talk and exchange their experiences with professionals, they could have autonomy and understand the importance promoting good habits in their lives.

\section{Critical reflection on diagnosis of the causes that interfere in educational actions in the FHS and proposition of new strategies}

This TU allowed professionals to reflect with propriety on the causes that interfere in the educational actions developed, as 
well as on the implementation of new strategies for improving these health education activities in daily life.

The professionals started with a deep reflection on the real meaning of the FHS, by rescuing its values and principles, because according to their perspectives, users still do not understand the real role of family health. This fact is often influenced by the way health care production is performed, centered on the logic of the biomedical model whose central focus is disease, as shown in the statements below:

<Interna/\|Focus Group 1>- § 8 coded references [4.53\% Coverage] Reference $1-0.42 \%$ Coverage: one of the things we can work on is the fact that population still has misconceptions about family health and we can work on that vision by improving our practices with the community, especially in strengthening educational actions. (Nurse/Anointed)

<Interna/ \Focus Group 2> Reference 2 - 0.14\% Coverage: they (users) are used to medical care and we need to change that. (CHA/Butterfly)

Professionals stressed the need to change their practices especially in relation to health education, where they critically review their relationship with users. They understand that strengthening the bond with the community is fundamental to change their curative conception in relation to the production of health care in the FHS.

<Interna/\Focus Group 1>- §8 coded references [4.53\% Coverage] Reference 3-0.39\% Coverage: we have issues with how we relate to them and we believe they only bond because we offer them something, but as you said, the point is that we improve our vision and work with them, being our partners. (CHA/Black)

$<$ Interna/ $\backslash$ Focus Group 1> Reference 6 - 0.65\% Coverage: if we do not change the way we act, especially in these educational actions, people in the community will only see the unit as a place where there is only one doctor attending and medicines to offer, that is, it will be seen. as a hospital. And this is not a hospital, it is a basic family unit. It's to have lectures, workshops, educational groups, songs, all a little. (CHA/Blue)

Problems such as lack of motivation, the overload of educational activities on only one or two professionals and the lack of commitment of the other components of the primary team are preventable when working with the co-responsibility of the actors involved in the process.

<Interna/ \Focus group 3> Reference 10 - 0.40\% Coverage: it is important to highlight that the educational actions must be performed by all of the health team, so we can do a job to strengthen the work of CHAs, as it is only in the hands of one or two professionals. get tired. (Nurse/Pink)

The problems raised and the practice of praxis were essential to remove those involved from the laziness, because from that, began to change attitudes towards educational practices. Partnerships were established with volunteers in the territory, such as musicians, artisans, traders, religious of different faiths, such as Evangelicals, Catholics, Spiritualists and people linked to Candomblé (Candomblé ("dance in honour of the gods") is an Afro-Brazilian religious tradition, practiced mainly in Brazil by the povo de santo ("people of saint")).

In addition to these valuable partnerships, two of the major problems raised by professionals, such as lack of management help and user participation in educational activities, have been overcome. Management began to actively participate not only in activities, but also in planning meetings, especially when we began structuring educational groups and creating new educational groups such as adolescent health, as they were willing to take this example of interaction and articulation of FHSt regarding educational actions for other units.

Regarding users, rather what was considered as limiting, given the almost complete absence of interest and minimal participation in educational practices, after the conceptual restructuring of the team, started to play a more active role in health promotion and prevention actions, participating and making a point of contributing to the group activities developed by the health team.

\section{Potentialities that encourage the development of educa- tional practices at FHU}

In this TU, it was possible to discuss and identify the potentialities that encourage the development of educational practices in FHU, thus emerging two UM, which are the empowerment of the CHA (Community Health Agent) for educational practice and appreciation of community participation.

\section{UM1- Empowerment of CHAs for educational practice}

According to the critical nodes revealed by FHS professionals regarding educational practices, this UM consolidates the suggestions listed by the professionals themselves to improve health education in the daily activities of $\mathrm{CHAs}$.

Due to the critical reflection process established by the FHSt, especially based on a recognition of frustration brought out most strongly by the $\mathrm{CHA}$, regarding its role in relation to educational practices, there was a feeling and a need to rescue the essence of the work of these professionals and give them back their spirits, self-esteem and their value in relation to health promotion and prevention actions, especially in relation to health education.

As Anointed and Pink say, medical professionals and nurses recognize that $\mathrm{CHAs}$ are essential in the FHS. Even in the face of existing barriers, they participated in group educational activities carried out in the unit, but in a timid manner. They have an externalized limitation due to the lack of conviction and recognition of their ability to conduct educational actions, whether group or individual, in the unit or in alternative spaces in the community, as stated below:

$<$ Interna/ $\backslash$ Focus Group 1 > - $\$ 13$ coded references [6.33\% Coverage] Reference 1 - 0.69\% Coverage: health workers have a very good knowledge of what is being done in the activities we do with the community, but we realize some shyness when it comes time to expose, to relate to the community and I think we should work something that they can is improving this, the relationship with users, because from there, they will be more encouraged and thus show its full potential. (Nurse/Anointed) 
$<$ Interna/ \Focus Group 1>- §13 coded references [6.33\% Coverage] Reference 2 - $0.36 \%$ Coverage: CHAs are professionals who know a lot, lacking willpower or feeling inhibited by the community and other professionals, either because they think they know less or because of the lack of bond. (Nurse/Pink)

The agents demonstrate how interested and sensitive they are in improving their work, highlighting the importance in the FG, action phase and action research evaluation, as they were able to think differently about the dynamics of action. They made them feel more motivated, thus enabling the implementation of more participatory educational strategies and recognizing their role in this context:

<Interna/\\Focus Group 1>- \$13 coded references [6.33\% Coverage] Reference $3-0,22 \%$ Coverage: each of us, the agent, is always prepared to participate in something that will bring changes to improve our activities. (CHA/Blue)

Reference 4- $0.70 \%$ Coverage: I can already see how important our work is and how we can improve it, we are having the opportunity to discuss, reflect on the work, and that's wonderful, it leaves us every time more motivated. I am here with many ideas on how to work in this more dialogical way. We are not standing, we are walking, we have to think about education strategies to improve our work more and more. (CHA/Black)

Reference 6 - 0.78\% Coverage: even physical activity we, the team, did with them, and that was dying, so people, we will, yes, improve our practices, maybe rescuing something we did before. Earlier in each micro area in the first meeting the nurse went only in the first meeting, in the other ones that we conducted and this made us have more autonomy. We prayed, we sang, we talked, where each one told their experiences with their children, that is very valid. (CHA/White)

During FG meetings, professionals, especially CHAs, internalized the precepts of dialogic health education and linked to this aroused the interest in participating more actively in educational actions. They were able to understand that the conduct of educational practices should not be restricted to nurses and physicians, because they were already unmotivated in relation to this concentration of educational activities.

In addition to the deep conviction that the bond with the community needs to be strengthened, $\mathrm{CHAs}$ sought to strengthen the team's commitment to educational practices through the implementation of a strengthening of educational strategies that encouraged the autonomy of agents in relation to educational actions. They rescued past educational practices and implemented new actions that encourage subject participation (professionals and users), guaranteeing the autonomy of health care.

$<$ Interna/ \Focus Group 5>- $\$ 9$ coded references [26.74\% Coverage] Reference $2-3.69 \%$ Coverage: we now have to plan, plan is very important and understand that we are all capable of developing an educational activity, whether the nurses or the doctor with us or not, we have to want and have the strength to will, so we'll do something really cool. And we can't stop sitting after the activities to evaluate the educational actions because we have to know what went right and what went wrong, always correcting these mistakes in the next meetings. (CHA/Black)
Reference 4-3.96\% Coverage: we have to split tasks and not focus on some only, because right or wrong, is the merit of all. Delegating responsibility is good because everyone has a different thinking and even a different ability, and that's good because the way we are thinking the educational actions will be very rich and will transform both our lives and the community's life. (CHA/Butterfly)

\section{UM2- Appreciation of community participation}

This UM expresses the need to value popular participation in the daily activities of FHU because of the distance between professionals and users in relation to health education actions. These are carried out without regard to popular knowledge, having an imposing, verticalized, normative and strictly technical and disease-centered character.

Through participant observation and FG, it was possible to perceive the feeling of the team in producing educational actions that value popular participation, the bond with the community and the development of participatory educational activities that consider the common knowledge of people about the experience of illness and illness. healing, acquired through your life story and culture. Given this desire to encourage popular participation in health care, follow testimonials from the FG:

<Interna/ \Focus Group 2>- §6 coded references [4.30\% Coverage] Reference 1 -098\% Coverage: we should always take actions to work with users in a participatory manner so that they can also expose their previous experiences and knowledge. He is our partner, as you said we should do educational actions with the user and not for the users to determine what he should do for his life by our understanding of health and disease. (Nurse/Pink)

Reference 3-0.30\% Coverage: that's right, we should work together with users and not simplyenter information into their lives. (CHA/Bee)

Reference 5 - $0.87 \%$ Coverage: in these educational actions, the only thing that matters is the way the professional arrives, relates to the user, arrives, has a good day, what will make this link is the professional and your way of acting, that is, the presence of the professional is of your importance and this way Mrs. João, Mrs. José will accept our work better. (CHA/Blue)

FHS team commitment to ensure community participation in the daily practices of FHU activities was contagious. Before the study, this participation was tiny, restricted to a mere transmission of information. However, now, in the research action and evaluation phase, we have an engagement and willpower to actually produce activities that are consistent with the theoretical precepts of dialogic education and significant in the lives of the subjects involved in the transformation process.

The participation of users in the planning process of the unit's educational activities had a considerable adherence, for example, in the process of creating an educational group of young people and adolescents. Volunteers already active in the community not only attended the implementation meetings, but were willing to work together with the health team. This was very rich, because the professionals had the opportunity to expand their network of collaborators and their line of action outside the restrictive curative context to health care. 


\section{Proposals for improving educational practices focused on soft health educational technology practiced in the dialogue dimension}

In this thematic unit, the professionals and users, through the FG, made proposals to improve the educational activities based on the soft health educational technology practiced in the dialogue dimension, an opportunity in which the team motivated renewed the commitment to develop participative educational activities.

Throughout the FG five meetings in the action phase and participant observation, in the evaluation phase, the research subjects debated, internalized concepts and promoted impacting transformations in the context of the health-disease process, mainly with regard to health education.

In addition to discussing the topic with great enthusiasm, the professionals were able to implement the ideas that emerged through the sharing of experiences, such as in the elderly group, where it was possible to improve the conversation circle with a more active participation of users, where they had more space to talk and demonstrate your conceptions through meaningful examples of your daily life.

In this context, the educational activities promoted after FG, as a result of FHS team planning and commitment, even made it possible to identify the potentialities of users in the educational groups. as, for example, a demand from professionals to implement music in educational activities, an opportunity in which a member of the group volunteered to expose their ability in educational activities. With that, every meeting of the elderly, besides the meaningful conversation round, had a moment of musicality, with a great local artist who loved to play guitar and sing.

Another need raised by the team and properly implemented was to explore the artistic skills of professionals in educational activities. Three CHAs who made crafts in their homes to supplement their family income were available to develop educational activities through their potential as artisans.

With this, they began their dialogical educational activities in the educational groups of pregnant women and the elderly, an opportunity in which for the first time they were able to conduct an educational action. In addition to having a meaningful conversation circle, they encouraged participants to produce art. In the elderly group, they made and taught users to paint on canvas, performing art therapy.

In the group of pregnant women, in addition to holding the conversation round, where they defined the name of the educational group and shared experience, produced art with recyclable materials, created cover for baby card, door identifier with the name of the child, among other products. In the other meetings, they performed specific exercises for and with pregnant women, with the participation of a volunteer physical therapy professional.

Validating the suggestions raised and put into practice by participants, let us look at the reports extracted from FG meetings:

$<$ Interna/ $\backslash$ Focus group $1>-\S 1$ coded reference [0.24\% Coverage] Reference 1-0,24\% Coverage: we can think of working with music, always in educational actions to have music, something that involves the user, that he also participates. (CHA/Red)
Reference 2 - $0.60 \%$ Coverage: we can explore here in the unit, which are: conversation and theater rounds, what to have in them, CHA participation with clear language, fun, participatory and objective dynamics, with very active users. (Nurse/Anointed)

$<$ Interna/ \Focus Group 4> - § 2 coded references [3.23\% Coverage] Reference 1 - $0.83 \%$ coverage: look, here in the unit we have three artisans, we can enhance this art in the educational actions here in the unit too, they work very well. (CHA /White)

Given this vast choice for the improvement and implementation of dialogue-based soft health education technologies raised by participants in this study, it was observed that the rounds of meaningful conversation, painting on canvas, handicraft making, photographic essay with pregnant women, use of music and inclusion of volunteers in educational activities emerge as an innovative strategy to be used during educational practices because it allows pregnant women, the elderly and adolescents an active participation and the possibility of assuming themselves as subjects during the development of the activity.

\section{DISCUSSION}

In a study by Machado et al. ${ }^{(17)}$, it was found that participatory educational interventions obtained positive results regarding adherence to non-pharmacological treatment of hypertension, in the sense of encouraging changes in lifestyle. The results indicated an improvement in anthropometric, biochemical and dietary parameters in all study groups, thus reaffirming the importance of continuous, participatory health education strategies based on the reality of the population served.

To ensure the effectiveness of educational actions and encourage user participation, dialogic educational strategies were used, such as health education workshops, exchange of experiences and experiences among members of the educational group, as well as taking into account your popular beliefs, cultures, myths and knowledge about healthy habits ${ }^{(17)}$.

This type of health education based on dialogue and social participation is a powerful tool for activities inherent to primary care in health services. It contributes significantly to promoting disease prevention and health promotion, the autonomy and co-responsibility of users, and, consequently, to improving the population's quality of life $\mathrm{f}^{(18)}$.

In view of this, the professional, as he detaches himself from a world rooted solely in technique and specialties, whose essence is to be the holder of truth, owner of reason, owners of knowledge that impose their reality of life, as well as their knowledge to lacking information and/or knowledge, he becomes a professional attuned to the basic precepts established by the FHS and definitely breaks with a vicious process that stigmatizes the health care promoted by primary care professionals ${ }^{(4)}$.

In this sense, praxis, action and reflection of professionals about the reality of the health-disease process in relation to health education activities, guarantees an authentic commitment to the reality posed, thus undoing an immutable and static care practice in face of the challenges of health promotion and prevention process, ensuring a broad, resolute and comprehensive transformation ${ }^{(4)}$.

Given this context, a survey conducted with professionals in Australia showed that the problematization of relevant topics, 
carried out through dialogical workshops, was essential to increase awareness, sensitization and improve the practices of primary health care professionals. It was essential to increase trust and recognition of the importance of health promotion and prevention through health education ${ }^{(19)}$.

Due to this transformative premise of education, it is necessary for professionals to be able to produce health actions together with users. They seek, therefore, the development of an enriching knowledge exchange relationship between popular and scientific knowledge, the result of which will be a change of practice and action in the health-disease process that will in fact truly produce social and life transformation ${ }^{(20)}$.

In this context, soft health technology allows the production of the relationships involved through the worker-user encounter through interaction, commitment and bonding, allowing us to understand the life context of users and the conditions that guide the production of health care, favoring a broader view of professionals. It enables a live act work whose main feature is based on user autonomy through active participation ${ }^{(11)}$.

A study explored the development of health education through interaction between users and professionals, where it was possible to build dynamic educational strategies that facilitated health care for the elderly. This fact was possible from the involvement of actors in the process of partnership and/or collective construction that considered the opinions of users, sometimes caregivers, demonstrating the value of soft educational technology in health as an indispensable tool in the process of empowerment of subjects ${ }^{(21)}$.

Corroborating the statements of Anointed, Pink and Blue, in another study, it was possible to show that closer relationships and the formation of partnerships with the community are fundamental to develop the educational practice outside and within the unit, through the use of spaces. such as churches, community centers, as well as the creation of educational groups such as teenagers, the elderly, etc. It is necessary to promote permanent and diversified educational practices, in order to establish a bond with the community and ensure that these activities produce improvement in the life context of users ${ }^{(13)}$.

From this, it becomes necessary to transform the traditional way of conducting the actions of health care production by professionals, as well as the traditional way of conducting health education groups. Therefore, going beyond recurrent biomedical topics such as illness, medications, complications and treatments, so that we can reach other topics such as leisure, exchange of popular experiences and healthy community cooking, based on light educational practice, centered on dialogue ${ }^{(22)}$.

Consolidating this thinking, a study by Stotz ${ }^{(23)}$, presenting a reflection on the $\mathrm{CHA}$ role as a mediator of educational actions based on the theory of Popular Education in Health, found that this health professional carries a potentiality in the process of mediation between knowledge and logic, being able to overcome the dichotomization of relations between health professionals and the population.

\section{Study limitations}

This study had the limitation of not including professionals from the Extended Family Health and Primary Care Center (NASFAB - Núcleo Ampliado de Saúde da Família e Atenção Básica).

\section{Contributions to nursing and public health}

This was the first study on this theme, conducted in a participatory manner with professionals and users in the Northern region. Articles published on health education in the FHS in Brazil, highlighted in the references of this article, showed that other Brazilian regions present similar educational experiences found in this research. Therefore, the need to broaden the process of improving meaningful educational practices based on the dimension of dialogue with FHS teams is emphasized.

The research points to the need for health professionals to intensify in the production of care a greater interaction with FHS users, having as a potential instrument the health education based on the dimension of dialogue. In this sense, this study significantly transformed the life context of the actors involved, being fundamental for the strengthening of educational practices at local, regional and national levels.

\section{FINAL CONSIDERATIONS}

The strategies used in the educational actions initially in the exploratory research phase were centered on traditional health education, predominantly through lectures, with little impact on users' lives, as they were limited to mere information transmission. Regarding the factors that influence the development of educational practices for health promotion in the FHS, we highlight the lack of ties with the community, vertical educational strategies, concentration of activities in consultations, prioritization of the population and professionals to care for the disease, lack of participation of professionals in educational activities, especially CHAs, and lack of adequate structure to develop educational actions.

With the proposals built collectively, educational practices were dynamic and creative, where population knowledge valorization was considered and optimized. Dialogic and participatory processes were fully developed and it was evidenced that FHS professionals and users are satisfied with the results achieved with the educational practices they develop, despite structural difficulties. At the end, in an evaluation meeting, study participants corroborated the results of this research.

\section{REFERENCES}

1. Alves VS. Um modelo de educação em saúde para o Programa Saúde da Família: pela integralidade da atenção e reorientação do modelo assistencial. Interface - Comun Saúde, Educ [Internet]. 2005[cited 2019 May 02];9(16):39-52. Available from: http://www.repositorio.ufba.br/ ri/handle/ri/10913 
2. PAIM JS. Saúde da Família: espaço de reflexão e de práticas contra-hegemônicas. In: Saúde, política e reforma sanitária. Salvador: Instituto de Saúde Coletiva; 2002. p. 447.

3. Pinheiro R, Luz MT. Práticas Eficazes x Modelos Ideais : Ação e Pensamento na Construção da Integralidade. Construção da Integr cotidiano, saberes e práticas em saude [Internet]. 2003[cited 2019 May 02];(1993):228. Available from: https://chasqueweb.ufrgs.br/ mauremramos/ outros/artigo_madel_roseni.pdf

4. Freire P. Educação e mudança. 2nd ed. São Paulo: Paz e Terra; 2011. 111 p.

5. Teixeira E, Costa e Silva BA, Pinto Fonseca J, Martins de Sousa Y, Barros Machado LC, Castro Portal L, et al. Educaçãoo em saúde: representação social e agir cotidiano de profissionais de saúde. O Mundo Saúde [Internet]. 2015[cited 2019 May 02];39(2):195-200. Available from: http://www.saocamilo-sp.br/pdf/mundo_saude/155570/A07.pdf

6. Sousa LB, Torres CA, Pinheiro PNC, Pinheiro AKB. Práticas de educação em saúde no Brasil: A atuação da enfermagem. Rev Enferm UERJ [Internet]. 2010[cited 2019 May 02];18(1):55-60. Available from: http://www.facenf.uerj.br/v18n1/v18n1a10.pdf

7. Roecker, Simone. Nunes EFP MS. Educação em saúde na estratégia saúde da família: o significado e a práxis dos enfermeiros. Esc Anna Nery. 2011;15(4):701-9. doi: 10.1590/S1414-81452011000400007

8. Salci MA, Maceno P, Rozza SG, Silva DMGV, Boehs AE, Heidemann ITSB. Educação em saúde e suas perspectivas teóricas: algumas reflexões. Texto Contexto Enferm. 2013;22(1):224-30. doi: 10.1590/S0104-07072013000100027

9. Pereira MDM, Pestana T, Maria E, Vaz C, Collet N. Conceptions and Practices of Professional Family Health Strategy for Health Education. Ciênc Saúde Coletiva. 2014;23(1):167-75. doi: 10.1590/S0104-07072014000100020

10. Alves GG, Aerts D. As práticas educativas em saúde e a Estratégia Saúde da Família. Ciênc saúde coletiva [Internet]. 2011;16(1):319-25. doi: $10.1590 /$ S1413-81232011000100034

11. Merhy EE. Saúde: a cartografia do trabalho vivo. 4a ed. São Paulo: HUCITEC; 2007.

12. Slomp Jr H, Feuerwerker LCM, Land MGP, Rizio TA, Thomas WJ, O'Brien AP, et al. Engaging primary healthcare nurses in men's health education: a pilot study. Saúde em Redes [Internet]. 2015[cited 2019 May 02];17(2):128-33. Available from: http://revista.redeunida.org.br/ ojs/index.php/rede-unida/article/view/309

13. Ramos CFV, Araruna RC, Lima MCF, Santana CLA, Tanaka LH. Education practices : research-action with nurses of Family Health Strategy. Rev Bras Enferm [Internet]. 2018[cited 2019 May 02];71(3):1144-51. Available from: http://www.scielo.br/pdf/reben/v71n3/0034-7167reben-71-03-1144.pdf

14. Cervera DPP, Parreira BDM Goulart BF. Educação em saúde: percepção dos enfermeiros da atenção básica em Uberada (MG). Ciênc Saúde Coletiva. 2011;30(7):1547-54. doi: 10.1590/S1413-81232011000700090

15. Thiollent M. Metodologia da pesquisa-ação. 18th ed. São Paulo: Cortez; 2011.

16. Sampieri RH, Collado CF, Lucio PB. O Processo da Pesquisa Qualitativa. In: Metodologia da Pesquisa. 5th ed. Porto Alegre: Penso; 2013. p. 624.

17. Machado JC, Cotta RMM, Moreira TR, Silva LS. Análise de três estratégias de educação em saúde para portadores de hipertensão arterial. Cien Saude Colet. 2016;21(2):611-20. doi: 10.1590/1413-81232015212.20112014

18. Oliveira EAF, Almeida AB, Souza ÉECM, Paula NCS, Pereira ER, Moreira RO, et al. [Meaning of hypertension educational groups to users of a primary care facility]. Rev APS [Internet]. 2011 [cited 2019 May 02];14(3):319-26. Available from: https://periodicos.ufjf.br/index.php/aps/ article/view/14771 Portuguese.

19. Rizio TA, Thomas WJ, O'Brien AP, Collins V, Holden CA. Engaging primary healthcare nurses in men's health education: A pilot study. Nurse Educ Pract. 2016;17:128-33. doi: 10.1016/j.nepr.2015.11.011

20. Gomes LB, Merhy EE. Compreendendo a educação popular em saúde: um estudo na literatura brasileira. Cad Saude Publica. 2011;27(1):718. doi: 10.1590/S0102-311X2011000100002

21. Cardoso RSS, Chaves Sá SP, Domingos AM, Sabóia VM, Maia TN, Padilha JMFO, et al. Tecnologia educacional: um instrumento dinamizador do cuidado com idosos [Internet]. 2016[cited 2019 May 02];71(suppl 2):197 f--197 f. Available from: http://www.repositorio.uff.br/jspui/ handle/1/2976

22. Mendonça FTNF, Santos AS, Buso ALZ, Malaquias BSS. Educação em saúde com idosos: pesquisa-ação com profissionais da atenção primária. Rev Bras Enferm. 2017;70(4):792-9. doi: 10.1590/0034-7167-2016-0349

23. Stotz EN, Maria H, Leal S, Bornstein VJ. O agente comunitário de saúde como mediador : uma reflexão na perspectiva da educação popular em saúde. Rev APS [Internet]. 2009[cited 2019 May 02];(2007):487-97. Available from: https://periodicos.ufff.br/index.php/aps/article/ view/14421 